\title{
PERAN PEMERINTAH DAERAH KABUPATEN/KOTA DALAM PENGAWASAN TENAGA KERJA ASING DI INDONESIA
}

\author{
La ode Dedihasriadi \\ Universitas Sembilanbelas November Kolaka | \\ Jl. Pemuda, Tahoa, Kolaka, Kabupaten Kolaka, Sulawesi Tenggara 9356 I \\ Id.dedihasriadi@gmail.com
}

\begin{abstract}
Article 33 paragraph (3) of the 1945 Constitution of the Republic of Indonesia implies that the natural resources which belong to the State are used for the prosperity of the people of Indonesia. Thus, in carrying out the mandate of the Constitution to create justice for the community and national economic development of employment including foreign workers, the government should provide a good mechanism and supervision so that there will be no gap between the mandate of the constitution and the acceleration of economic development involving foreign workers. Labor inspection done by a separate working unit in the agency whose scope of duties and responsibilities is in the field of employment is in the central government, provincial government, and district/ city government. This study used a normative-empirical approach, where the researcher examined the law and its implementation regarding the roles of district/ city governments in the supervision of foreign workers. The purpose of this study was to examine the extent of the roles of district/ city governments in overseeing foreign workers in their regions. The results of the study showed that the roles of district/ city governments in carrying out the supervision of foreign workers in Indonesia were not regulated by laws of No. 23 of 2014 concerning regional government, PP No. 20 of 2018 concerning the use of foreign workers, and Minister of Manpower Regulation No. 10 of 2018 concerning procedures for the use of foreign workers. Thus, its implementation made it difficult for district/ city governments to oversee the presence of foreign workers in their areas.
\end{abstract}

Keywords: Supervision, Local Government and Foreign Workers. 
Abstrak: Pasal 33 ayat (3) UUD 1945, mengisyaratkan bahwa kekayaan alam yang terkandung di dalam negara dipergunakan untuk kemakmuran rakyat, maka pemerintah dalam menjalankan amanah konstitusi. Agar terciptanya keadilan bagi masyarakat dan pembagunan ekonomi nasional lapangan kerja yang melibatkan tenaga kerja asing, haruslah ada mekanisme dan pengawasan yang baik agar tidak terjadinya kesenjangan antara amanat konstitusi dengan percepatan pembangunan ekonomi yang melibatkan tenaga kerja asing. Pengawasan ketenagakerjaan oleh unit kerja tersendiri pada instansi yang lingkup tugas dan tanggung jawabnya di bidang ketenagakerjaan pada pemerintah pusat, pemerintah provinsi, dan pemerintah kabupaten/kota. Metode penelitian ini adalah pendekatan normatifempiris, di mana penelitian tersebut mengkaji undang-undang dan implementasinya terhadap peran pemerintah daerah kabupaten/kota dalam pengawasan tenaga kerja asing. Tujuan penelitian ini adalah untuk mengkaji sejauhmana peran pemerintah daerah kabupaten/kota dalam mengawasi tenaga kerja asing di daerahnya. Hasil penelitian menunjukkan bahwa peran pemerintah daerah kabupaten/kota dalam melaksanakan pengawasan tenaga kerja asing di Indonesia tidak diatur oleh UU. No. 23 Tahun 2014 tentang Pemerintahan Daerah, PP No. 20 Tahun 2018 Penggunaan Tenaga Kerja Asing dan Permen Ketenagakerjaan No. 10 Tahun 2018 tentang Tata Cara Penggunaan Tenaga Kerja Asing. Sehingga implementasinya menyulitkan pemerintah daerah kabupaten/kota dalam mengawasi keberadaan tenaga kerja asing yang berada di daerahnya.

Kata Kunci: Pengawasan, Pemerintah Daerah dan Tenaga Kerja Asing.

\section{Pendahuluan}

Indonesia adalah negara dengan kekayaan alam melimpah yang menuntut adanya pengelolalaan yang baik. Jika dikelola secara serampangan, maka kekayaan alam yang kita miliki itu tidak bisa bermanfaat bagi rakyat dan bangsa. Dalam hal kekayaan alam, khususnya industri dan pertambangan, pengelolaan dilakukan oleh Badan Usaha Milik Negara dan/atau Badan Usaha Milik Swasta yang berada dalam negeri. Kondisi demikian harus ditopang dengan sumber daya manusia yang memadai dengan skill atau 
penguasaan keahlian-keahlian yang tepat dalam pengelolaan sumber daya alam yang ada di Indonesia.

Terkait dengan sumber daya alam dalam negeri, bumi, air dan ruang angkasa, termasuk kekayaan alam yang terkandung di dalamnya itu pada tingkatan tertinggi dikuasai oleh negara, sebagai organisasi kekuasaan seluruh rakyat. Semua digunakan untuk mencapai sebesar-besarnya kemakmuran rakyat, dalam arti kebahagiaan, kesejahteraan dan kemerdekaan dalam masyarakat dan negara hukum Indonesia yang merdeka berdaulat, adil dan makmur.

Dewasa ini Indonesia menghadapi masalah ketenagakerjaan yang sangat serius. ${ }^{1}$ Salah satunya minimnya tenaga kerja ahli dalam negeri khususnya masyarakat Indonesia yang menguasai keahlian dalam bidang tertentu terkait teknologi baru yang di gunakan pada pembangunan infrastruktur dengan kecanggihan teknologi saat ini. Untuk mempercepat pembangunan industri dan pertambangan maka diperlukan tenaga kerja ahli dalam pengelolaan sumber daya alam yang ada di Indonesia khususnya industri dan pertambangan. Untuk mencapai kebutuhan tenaga kerja ahli, keterlibatan tenaga kerja asing tidak bisa kita elakkan kerena. Bagaimanapun, memperoleh tenaga kerja ahli di bidang tertentu yang sesuai dengan kebutuhan dalam negeri merupakan keniscayaan.

Dalam mengisi kekosongan keahlian dan dan kompetensi di bidang tertentu yang tidak dapat dipegang oleh tenaga kerja Indonesia, maka tenaga kerja asing dapat dipekerjakan di Indonesia sepanjang memenuhi ketentuan peraturan perundang-undangan. ${ }^{2}$ Penggunaan Tenaga Kerja Asing (TKA) dilakukan oleh pemberi kerja Tenaga Kerja Asing (TKA) dalam hubungan kerja untuk jabatan tertentu dan waktu tertentu. ${ }^{3}$ Hal ini berlaku dengan

\footnotetext{
' Frankiano B. Randang, Kesiapan Tenaga Kerja Indonesia dalam Menghadapi Persaingan dengan Tenaga Kerja Asing, SERVANDA, Jurnal Ilmiah Hukum, Vol. 5, No. I, 20I I, 66.

2 Zaeni Asyhadie dan Rahmawati Kusuma, Hukum Ketenagakerjaan dalam Teori \& Praktik di Indonesia, (Jakarta: Kencana, 2019), 273.

${ }^{3}$ Perpres No. 20 Tahun 20 I 8 Bab II Pasal 2 ayat (I).
}

\section{$325 \mid$\begin{tabular}{l|l} 
al-Daulah \\
Vol. 9. no.2. Oktober 2019
\end{tabular}}


ketentuan bahwa pemberi kerja yang menggunakan tenaga kerja asing harus memiliki rencana penggunaan tenaga kerja asing yang disahkan oleh Menteri atau pejabat yang ditunjuk. ${ }^{4}$ Tenaga kerja asing juga dapat dipekerjakan di Indonesia hanya dalam hubungan kerja untuk jabatan tertentu dan waktu tertentu. ${ }^{5}$

Pasal 33 ayat (3) Undang-undang Dasar Negara Republik Indonesia (UUD NRI) Tahun 1945 menyebutkan, “bumi dan air dan kekayaan alam yang terkandung di dalamnya dikuasai oleh negara dan dipergunakan untuk sebesar-besar kemakmuran rakyat". ${ }^{6}$ Pasal tersebut mengisyaratkan bahwa kekayaan alam yang terkandung di dalam negara dipergunakan untuk kemakmuran rakyat. Atas dasar inilah, pemerintah sebagai penegak hukum harus senantiasa menjalankan amanah konstitusi yang berlaku. Salah satu bentuk amanat konstitusi negara adalah memberikan perlindungan dan pengawasan lapangan kerja agar terciptanya keadilan bagi masyarakat dan pembagunan ekonomi nasional yang melibatkan tenaga kerja asing. Hal ini bertujuan agar tidak terjadi kesenjangan antara amanat konstitusi dengan percepatan pembangunan ekonomi yang melibatkan tenaga kerja asing sebagaimana termaktub dalam Pasal 27 ayat (2) UUD NRI 1945 bahwa "tiap-tiap warga negara berhak atas pekerjaan dan penghidupan yang layak bagi kemanusiaan."

Mengingat keberadaan lapangan kerja membutuhkan keahlian khusus dan jabatan tertentu, maka pengawasan ketenagakerjaan dilakukan oleh pegawai pengawas ketenagakerjaan yang mempunyai kompetensi dan independensi dalam menjamin pelaksanaan peraturan perundang-undangan ketenagakerjaan. ${ }^{7}$ Pengawasan ketenagakerjaan dilakukan oleh unit kerja tersendiri pada instansi yang lingkup tugas dan tanggung jawabnya di bidang

\footnotetext{
${ }^{4}$ UU No. 13 Tahun 2003 Bab VIII Pasal 43 ayat ( I).

${ }^{5}$ UU No. 13 Tahun 2003 Bab VIII Pasal 42 ayat (4)

${ }^{6}$ UUD NRI Tahun 1945.

${ }^{7}$ UU No. 13 Tahun 2003 Bab XIV Pasal 176 ayat ( I).
} 
ketenagakerjaan pada pemerintah pusat, pemerintah provinsi, dan pemerintah kabupaten/kota. ${ }^{8}$

Berdasarkan ketentuan Pasal 18 ayat (1) UUD NRI Tahun 1945 bahwa, "Negara Republik Indonesia dibagi atas daerah-daerah provinsi dan daerah provinsi itu dibagi atas kabupaten dan kota, yang tiap-tiap provinsi, kabupaten, dan kota mempunyai pemerintah daerah, yang diatur dengan undang-undang". Sebagai negara hukum, setiap penyelenggaraan urusan pemerintahan haruslah berdasarkan hukum yang berlaku (wetmatigheid van bestuur). ${ }^{9}$

Pasal 18 ayat (5) UUD NRI Tahun 1945 menyebutkan bahwa; pemerintahan daerah menjalankan otonomi seluas-luasnya, kecuali urusan pemerintahan yang oleh undang-undang ditentukan sebagai urusan pemerintahan pusat. Pada Prinsipnya demokrasi merupakan bagian yang tak terpisahkan dalam penyelenggaraan otonomi daerah. Demokrasi memberikan setiap daerah kebebasan untuk mengatur dan menyelenggarakan pemerintahan daerah sesuai kehendak masyarakat daerah. Demokrasi dalam konsteks daerah memberikan kebebasan kepada setiap daerah untuk mengembangkan diri sesuai kehendaknya. Dengan demikian, prinsip demokrasi memberikan hak dan kebebasan kepada daerah untuk mengurus dan melaksanakan kehendak daerah sesuai konsepsi otonomi daerah. ${ }^{10}$

Oleh karena itu, penulis tertarik untuk mengkaji sejauh mana kebebasan Peran Pemerintah Daerah kabupaten/kota Dalam Pengawasan Tenaga Kerja Asing di Indonesia yang di amanatkan oleh peraturan perundang-undangan?

\footnotetext{
8 UU No. 13 Tahun 2003 Bab XIV Pasal 178 ayat (I).

${ }^{9}$ Ridwan Hr, Hukum Administrasi Negara, (Jakarta: RajaGrafindo, 2006), 17.

10 Fuqoha, "Peraturan Daerah Bermuatan Syariat Islam Ditinjau dari Prinsip Demokrasi Konstitusional", Al-Daulah: Jurnal Hukum dan Perundangan Islam, Vol. 8, No. I, 20I8, 4.
} 


\section{Metode Penelitian}

Metode yang digunakan dalam penelitian ini adalah yuridisempiris. Ada dua indikator yang akan dianalisis yaitu undangundang dan implementasinya. Pengumpulan data primer dengan pendekatan normatif ditempuh oleh peneliti dengan meneliti norma-norma yang terdapat dalam undang-undang. Adapun pendekatan secara empiris ditempuh dengan mengkaji implementasi undang-undang tersebut melalui metode wawancara kepada Pemerintah Daerah Kabupaten Kolaka dengan sumber data Dinas Tenaga Kerja dan Transmigrasi Kabupaten Kolaka. Data yang diperoleh selanjutnya dianalisis dengan menggabungkan melalui pendekatan normatif dan empiris untuk mengetahui peran pemerintah daerah dalam pengawasan tenaga kerja asing.

Penelitian ini dilaksanakan di Kabupaten Kolaka sebagai sampel dari seluruh wilayah pemerintah daerah kabupaten/kota di Indonesia. Tujuan penelitian ini adalah untuk mengetahui informasi yang mendalam tentang peran pemerintah daerah kabupaten/kota di Indonesia dalam pengawasan tenaga kerja asing.

\section{Pembahasan}

Perjalanan otonomi daerah di Indonesia merupakan isu menarik untuk diamati dan dikaji. Pada hakikatnya, semenjak para pendiri negara menyusun format negara, isu menyangkut pemerintahan lokal telah diakomodasi dalam pasal 18 UUD 1945 beserta penjelasannya. ${ }^{11}$ Hadirnya pemerintah daerah dalam sistem pemerintahan di Indonesia merupakan suatu bagian yang tidak terpisahkan dari suatu sistem pemerintahan negara atau pemerintahan nasional. Bahkan, secara konsep dan teoritis keberadaan pemerintah daerah jauh lebih dahulu daripada keberadaan unsur pemerintahan pusat atau pemerintahan negara

I Darmini Roza dan Laurensius Arliman S, "Peran Badan Permusyawaratan Desa di Dalam Pembangunan Desa Dan Pengawasan Keuangan Desa", PADJAJARAN: Jurnal IImu Hukum, Vol. 4 No. 3, 2017, 606. 
terbentuk.12 Keberadaan otonomi daerah menjadi momen penting untuk mengetahui apa saja yang telah di capai bangsa ini dalam melaksanakannya. ${ }^{13}$ Pemerintahan daerah adalah penyelenggaraan urusan pemerintahan oleh pemerintah daerah dan Dewan Perwakilan Rakyat Daerah menurut asas otonomi dan tugas pembantuan dengan prinsip otonomi seluas-luasnya dalam sistem dan prinsip negara kesatuan republik Indonesia sebagaimna di maksud dalam UUD NRI Tahun 1945. ${ }^{14}$

Dalam ketentuan ini pemerintah daerah diberikan kewenangan untuk merekonstruksi pembangunan baik dari segi pembangunan infrastruktur maupun pembangunan sumber daya manusia di lingkup kekuasaannya demi tercapainya pemerataan kesejahteraan dan kemakmuran oleh masyarakat pemerintah daerah sehingga dapat mencapai cita-cita yang diamanatkan oleh konstitusi. Sedangkan otonomi daerah adalah hak, wewenang, dan kewajiban daerah otonom untuk mengatur dan mengurus sendiri Urusan pemerintahan dan kepentingan masyarakat setempat dalam sistem Negara Kesatuan Republik Indonesia. ${ }^{15}$

Tujuan otonomi daerah adalah untuk mencapai efektivitas dan efesiensi dalam pelayanan publik. Sedangkan yang ingin dicapai dalam penyerahan urusan ini antara lain yaitu menumbuhkembangkan daerah dalam berbagai bidang, meningkatkan pelayanan kepada masyarakat, dan meningkatkan daya saing daerah dalam proses pertumbuhan. ${ }^{16}$ Lebih lanjut Sarundajang mengartikan otonomi daerah sebagai berikut: ${ }^{17}$

\footnotetext{
12 Rahyunir Raup, Asas Penyelenggaraan Pemerintah Daerah, (Pekanbaru: Zanafa Publishing, 20I8), 23.

13 Dian Ferricha, "Tanggung Jarab Pemerintah Daerah pada Penempalan dan Perlindungan Tenaga Kerja Indonesia Menuju Negara Kesejahteraan", AHKAM, Vol. 4, No. I, 2016, I4I.

14 UU No. 23 Tahun 20 I4 Bab I Pasal I ayat (2).

15 UU No. 23 Tahun 2014 Bab I Pasal 6.

16 Haw. Widjaya, Otonomi Daerah Dan Daerah Otonom, (Jakarta: Raja Grafindo Persada, 2004), $21-22$.

17 Ibid., 34.
} 
1. hak mengurus rumah tangga sendiri bagi suatu daerah otonom, hak tersebut bersumber dari wewenang pangkal dan urusanurusan pemerintah (pusat) yang diserahkan kepada daerah

2. dalam kebebasan menjalankan hak mengurus dan mengatur rumah tangga sendiri, daerah tidak dapat menjalankan hak dan wewenang otonomnya itu diluar batas-batas wilayah daerahnya

3. daerah tidak boleh mencampuri hak mengatur dan mengurus rumah tangga daerah lain sesuai dengan wewenang pangkal dan urusan yang diserahkan kepadanya.

4. otonomi tidak membawahi otonomi daerah lain.

Untuk itu, tujuan utama peran pemerintah daerah dalam otonomi daerah adalah meningkatnya pelayanan publik dan kesejahteraan masyarakat. Ukuran keberhasilannya adalah terwujudnya kehidupan yang lebih baik dan adil dalam hal pendapatan dan terciptanya rasa aman. Salah satu aspek penting lain adalah pemberdayaan masyarakat sehingga dapat berpartisipasi dalam proses perencanaan, pelaksanaan, dan pengawasan serta penyelenggaraan layanan publik.

Lebih lanjut peran pemerintah daerah dalam otonomi daerah dengan menggunakan prinsip otonomi seluas-luasnya dalam arti daerah diberikan kewenangan mengurus dan mengatur semua urusan pemerintahan yang ditetapkan dalam undang-undang. Dengan demikian, daerah memiliki kewenangan dalam membuat kebijakan dalam memberikan pelayanan, peningkatan peran serta, prakarsa, dan pemberdayaan masyarakat yang bertujuan pada peningkatan kesejahteraan. ${ }^{18}$

Sebagaimana juga dinyatakan oleh Ryaas Rasyid bahwa keberadaan utama pemerintahan pada hakikatnya merupakan pelayanan kepada masyarakat. Pemerintahan tidak diadakan untuk melayani kepentingan dirinya sendiri, melainkan untuk kebutuhan masyarakat. Selain itu untuk menciptakan kondisi yang

18 Juniarso Ridwan dan Achmad Sodik Sudrajat, Hukum Administrasi Negara dan Kebijakan Pelayanan Publik, (Bandung: Nuansa, 2012), 129-130. 
memungkinkan setiap anggota masyarakat dapat mengembangkan kemampuan dan kreativitasnya demi mencapai tujuan bersama. ${ }^{19}$

\section{Peran Pemerintah Daerah Kabupaten/kota dalam Pengawasan Tenaga Kerja Asing}

Dalam Pasal 18 ayat (5) UUD NRI Tahun 1945 disebutkan bahwa; pemerintahan daerah menjalankan otonomi seluas-luasnya, kecuali urusan pemerintahan yang oleh undang-undang ditentukan sebagai urusan pemerintahan pusat.

Urusan pemerintahan terdiri atas urusan pemerintahan absolut, urusan pemerintahan konkuren dan urusan pemerintahan umum. ${ }^{20}$ Urusan pemerintahan konkuren adalah urusan yang dibagi antara pemerintahan pusat dan daerah provinsi dan daerah kabupaten/kota. Dalam urusan ini yang menjadi kewenangan daerah adalah urusan pemerintahan wajib yang berkaitan dengan pelayanan dasar di antaranya meliputi :21
a. pendidikan
b. kesehatan
c. pekerjaan umum dan penataan ruang
d. perumahan rakyat dan kwasan pemukiman
e. ketentraman, keteriban umum dan perlindungan masyarakat; dan
f. sosial.

Daerah juga mempunyai urusan pemerintahan wajib yang tidak berkaitan dengan pelayanan dasar yang meliputi :22
a. tenaga kerja
b. pemberdayaan perempuan dan perlindungan anak
c. pangan
d. pertanahan
e. lingkungan hidup

\footnotetext{
${ }^{19}$ Aminuddin Ilmar, Hukum Tata Pemerintahan, (Jakarta: Kencana, 20 I 4), I I .

20 UU No. 23 Tahun 2014 Bab IV Pasal 9 ayat (I).

21 UU No. 23 Tahun 2014 Bab IV Pasal 12 ayat (I).

22 UU No. 23 Tahun 2014 Bab IV Pasal 12 ayat (2).
} 
f. administrasi kependudukan dan catatan sipil

g. pemberdayaan masyarakat dan desa

h. pengendalian penduduk dan keluarga berencana

i. perhubungan

j. komunikasi dan informatika

k. koperasai, usaha kecil dan menengah

1. penanaman modal

$\mathrm{m}$. kepemudaan dan olah raga

n. statistik

o. persandian

p. kebudayaan

q. perpustakaan, dan

r. kearsipan.

Lebih lanjut pembagian urusan pemerintahan konkuren antara pemerintah pusat dan daerah provinsi serta daerah kabupaten/kota harus didasarkan prinsip akuntabilitas, efisiensi dan eksternalitas serta kepentingan nasional. ${ }^{23}$ Dalam konteks ini yang menjadi urusan pemerintah pusat adalah; ${ }^{24}$

1. Urusan pemerintah yang lokasinya lintas daerah provinsi atau lintas negara,

2. Urusan pemerintahan yang penggunaanya lintas daerah provinsi atau lintas negara,

3. Urusan pemerintahan yang manfaat atau dampak negatifnya lintas daerah provinsi atau lintas negara,

4. Urusan pemerintahan yang penggunaan sumber dayanya lebih efisien apabila dilakukan oleh pemerintah pusat,

5. Urusan pemerintahan yang peranannya strategis bagi kepentingan nasional.

Esensi dari pada penyelenggaraan pemerintahan di daerah kabupaten/kota adalah berkaitan dengan kewenangan yang dimiliki dalam mengurus dan mengatur rumah tangganya demi tercapainya percepatan pembagunan dan kesejahteraan, salah

${ }^{23}$ UU No. 23 Tahun 20 I 4 Bab IV Pasal 13 ayat (I).
${ }^{24}$ UU No. 23 Tahun 20 I 4 Bab IV Pasal 13 ayat (2). 
satunya adalah mengawasi keberadaan tenaga kerja asing di daerahnya. Namun, eksistensi penyelenggaraan pemerintah daerah dalam otonomi daerah khususnya daerah kabupaten/kota terhambat oleh keberadaan Undang-Undang Nomor 23 Tahun 2014 tentang Pemerintahan Daerah (UU No. 23 Tahun 2014) sebagai landasan yuridis penyelenggaraan pemerintahan itu sendiri khususnya dalam bidang pangawasan tenaga kerja asing yang hendak berada dan bekerja di daerah kabupaten kota. Problematika peran pemerintahan daerah kabupaten/kota dalam pengawasan tenaga kerja asing tertuang secara yuridis dalam UU Nomor 23 Tahun 2014 yang antara lain termaktub dalam:

Pasal 15 ayat (1): "pembagian urusan pemerintahan konkuren antara pemerintah pusat dan daerah provinsi serta daerah kabupaten/kota tercantum dalam lampiran yang merupakan bagian yang tak terpisahkan dari undang-undang ini".

Pasal 15 Ayat (2): "urusan pemerintahan konkuren yang tidak tercantum dalam lampiran undang-undang ini menjadi kewenangan tiap tingkatan atau susunan pemerintahan...".

Berikut ini kewenangan tiap tingkatan pemerintahan berdasarkan pembagian urusan pemerintahan bidang tenaga kerja sebagaimana diatur dalam Pasal 15 ayat (2) UU No 23 Tahun 2014.

Tabel 1. Kewenangan Pengawasan Tenaga Kerja

\begin{tabular}{|l|l|l|l|}
\hline Sub Bidang & $\begin{array}{c}\text { Pemerintah } \\
\text { Pusat }\end{array}$ & \multicolumn{1}{|c|}{$\begin{array}{c}\text { Daerah } \\
\text { Provinsi }\end{array}$} & $\begin{array}{c}\text { Daerah } \\
\text { Kab/Kota }\end{array}$ \\
\hline Pengawasan & a. Penetapan & Penyelenggara & \\
Tenaga Kerja & sistem & an & \\
& pengawasan & Pengawasan & \\
& ketenaga- & ketenaga- & \\
& kerjaan & kerjaan & \\
& b. Pengelolaan & & \\
& tenaga & & \\
& pengawas & & \\
& ketenaga- & & \\
& kerjaan & & \\
\hline
\end{tabular}


Keberadaan Pasal 15 ayat (1) dan (2) UU No. 23 Tahun 2014 di atas diperkuat dengan lahirnya peraturan lain yang ada di bawahnya yaitu Peraturan Presiden Nomor 20 Tahun 2018 tentang Penggunaan Tenaga Kerja Asing (Perpres No. 20 Tahun 2018) yang "memangkas" kewenangan daerah kabupaten/kota dalam mengawasi keberadaan tenaga kerja asing di Indonesia. Ketentuan Perpres tersebut tertuang dalam Pasal 33 ayat (1) huruf a: "pengawasaan tenagakerjaan pada kementerian dan dinas provinsi yang membidangi urusan di bidang ketenagakerjaan " serta Pasal 33 ayat (3): "pengawasan pendidikan dan pelatihan tenaga kerja pendamping dilakukan oleh pengawas ketenagakerjaan pada kementerian dan dinas provinsi yang membidangi urusan di bidang ketenagakerjaan secara bersama-sama atau sendiri-sendiri sesuai dengan lingkup tugas dan kewaenagngannya masing-masing."

Selain itu, peraturan turunan lebih teknis yang mengatur pengawasan keberadaan tenaga kerja asing ( TKA ) juga tidak dijumpai sebagaimana tertuang dalam Peraturan Menteri Ketenagakerjaan Nomor 10 Tahun 2018 tentang Tata Cara Penggunaan Tenaga Kerja Asing Pasal 37 (Permen Ketenagakerjaan No. 10 Tahun 2018) yang menyatakan, "pengawasan terhadap pemberi kerja tenaga kerja asing yang menggunakan tenaga kerja asing serta pelaksanaan pendidikan dan pelatihan tenaga kerja pendamping dilaksanakan oleh pengawas ketenagakerjaan pada kementerian ketenagakerjaan dan dinas provinsi secara bersama-sama atau sendirisendiri sesuai dengan lingkup tugas dan kewenangan masing-masing".

Dalam implementasinya kewenangan pemerintah daerah kabupaten/kota, khususnya Kabupaten Kolaka, dalam melaksanakan pemantauan, pendataan dan pengawasan tenaga kerja asing hanya bersifat suka rela. Dalam konteks ini, tuntutan penambahan jumlah tenaga kerja asing di sebuah perusahaan tidak 
bisa dilakukan. Mengingat, tidak ada ruang hukum yang bisa memberikan kewenangan untuk bertindak demikian. ${ }^{25}$

Jika merujuk pada regulasi di atas, tentu tidak ada peluang yuridis bagi pemerintah daerah kabupaten/kota untuk mengawasi tenaga kerja asing di daerahnya. Tentu hal ini jelas bertentangan dengan keberadaan dan prinsip lahirnya otonomi daerah yang mendorong percepatan pembangunan infrastrukstur maupun SDM melalui penyerahaan penyelenggaraan daerah demi tercapainya kesejahteraan masyarakat.

Pembangunan daerah adalah bagian integrasi dari pembangunan nasional yang tidak bisa dilepaskan dari prinsip otonomi daerah. Sebagai daerah otonom, suatu daerah harus memiliki kewenangan dan tanggung jawab dalam menyelenggarakan kepantingan masyarakat berdasarkan prinsip, keterbukaan, partisipasi dan pertanggungjawaban kepada masyarakat. ${ }^{26}$

Segala potensi yang bersumber dari dalam daerah kabupaten/kota yang akan digunakan untuk pembangunan baik infrastruktur maupun sumber daya manusia hanya akan dipahami secara detail oleh daerah itu sendiri. Begitupun sebaliknya tantangan dan hambatan yang dihadapi oleh daerah otonomi kabupaten/kota hanya akan didiketahui dan dirasakan oleh daerah itu sendiri sehingga tidaklah "elok" undang-undang sebagai landasan yuridis penyelenggaran pemerintahan daerah kabupaten/kota tidak memberikan ruang dalam proses pengawasan keberadaan tenaga kerja asing yang masuk dan berkerja di wilayah daerah otonom kabupaten/kota.

Keberadaan tenaga kerja asing di Indonesia memang dibutuhkan sebagai langkah untuk mendorong percepatan pembangunan bangsa Indonesia. Sebagaimana komitmen ini di tuangkan dalam Perpres No. 20 Tahun 2018 Pasal 2 ayat (1) bahwa

\footnotetext{
25 Wawancara dengan Bapak Hartono, Kabid Hubungan Industri, Dinas Tenaga Kerja dan Transmigrasi, Kab. Kolaka, I6 juli 2019, Pukul I I.00 Wita.

${ }^{26}$ Juniarso Ridwan dan Achmad Sodik Sudrajat, Hukum Administrasi Negara... , 1 I 6.
} 
penggunaan tenaga kerja asing di lakukan oleh pemberi kerja tenaga kerja asing dalam hubungan kerja untuk jabatan tertentu dan waktu waktu tertentu. Tentunya pemerintah daerah mendukung keberadaan tenaga kerja asing di Indonesia sebagai bagian dari akselerasi pembangunan, akan tetapi harus seiring dengan terintegrasinya pengawasannya di daerah khususnya kabupaten/kota. Sehingga terciptanya peran dan transparansi serta keterlibatan masyarakat dalam mencapai kesejahteraan masyarakat di daerah.

\section{Penutup}

Berdasarkan penelitian di atas, secara normatif peran pemerintah kabupaten/kota dalam pengawasan keberadaan tenaga kerja asing di tidak mempunyai payung hukum baik yang tertuang dalam UU No. 23 Tahun 2014, Perpres No. 20 Tahun 2018, maupun Permen Ketenagakerjaan No. 10 Tahun 2018.

Sedangkan dalam tataran implementasinya tindakan pengawasan terhadap keberadaan tenaga kerja asing yang bekerja dalam lingkungan pemerintah daerah kabupaten/kota tidak pernah dilakukan. Hal ini dikarenakan undang-undang maupun peraturan lainnya sebagai payung hukum tidak memberikan celah hukum kepada pemerintah daerah kabupaten/kota untuk mengawasi keberadaan tenaga kerja asing di daerahnya.

\section{Daftar Pustaka}

Asyhadie, Zaeni dan Rahmawati Kusuma. Hukum Ketenagakerjaan dalam Teori \& Praktik di Indonesia. Jakarta: Kencana, 2019.

Ferricha, Dian. “Tanggung Jawab Pemerintah Daerah pada Penempatan dan Perlindungan Tenaga Kerja Indonesia Menuju Negara Kesejahteraan", AHKAM, Volume. 4, Nomor. 1, (2016). 
Fuqoha. "Peraturan Daerah Bermuatan Syariat Islam Ditinjau Dari Prinsip Demokrasi Konstitusional". Al-daulah: Jurnal Hukum dan Perundangan Islam, Volume. 8, Nomor 1, (2018).

Hartono, Kabid Hubungan Industri, Dinas Tenaga Kerja dan Transmigrasi, Kab. Kolaka. Wawancara, 16 juli 2019.

Ilmar, Aminuddin. Hukum Tata Pemerintahan. Jakarta: Kencana, 2014.

Peraturan Menteri Ketenagakerjaan Nomor 10 Tahun 2018 tentang Tata Cara Penggunaan Tenaga Kerja Asing.

Peraturan Presiden Nomor 20 Tahun 2018 tentang Penggunaan Tenaga Kerja Asing.

Randang, Frankiano B. "Kesiapan Tenaga Kerja Indonesia dalam Menghadapi Persaingan Dengan Tenaga Kerja Asing". SERVANDA, Jurnal Ilmiah Hukum, Volume. 5, Nomor. 1, (2011).

Raup, Rahyunir. Asas Penyelenggaraan Pemerintah Daerah. Pekanbaru: Zanafa Publishing, 2018.

Ridwan, Juniarso dan Achmad Sodik Sudrajat. Hukum Administrasi Negara Dan Kebijakan Pelayanan Publik. Bandung: Nuansa, 2012.

Roza, Darmini dan Laurensius Arliman S. "Peran Badan Permusyawaratan Desa di dalam Pembangunan Desa dan Pengawasan Keuangan Desa". PADJAJARAN: Jurnal Ilmu Hukum, Volume. 4 Nomor. 3, (2017).

Undang-Undang Dasar Negara Republik Indonesia Tahun 1945.

Undang-Undang Nomor 23 Tahun 2014 tentang Pemerintahan Daerah.

UU Nomor 13 Tahun 2003 tentang Ketenagakerjaan.

Widjaya, Haw. Otonomi Daerah Dan Daerah Otonom. Jakarta: Raja Grafindo Persada, 2004. 